\title{
Развитие лексической стороны речи детей с церебральным параличом
}

\author{
Лаврентьева А.Н., \\ заместитель директора ГБУ РС(Я) «РРЦ г. Нерюнгри» \\ E-mail: rcr-dcp9@yandex.ru
}

Детский церебральный паралич характеризуются двигательными, психическими, речевыми отклонениями. Несомненно, ограниченность или невозможность произвольных движений тормозит общее развитие ребенка, обуславливает недостаток сенсомоторного развития, ориентировочно-исследовательских реакций, недоразвитие познавательной деятельности, ограниченность общения, психические и речевые расстройства (Л.О. Бадалян, С.А. Бортфельд, М.Н. Гончарова, Н.Н. Ефименко, Л.Т. Журба, М.В. Ипполитова, Е.Т. Лильин, Е.М. Мастюкова, Н.М. Махмудова, К.А. Семенова, М.Я. Смуглин, В.Г. Тактаров и др.).

Характер двигательных, психических, речевых нарушений у каждого ребенка индивидуален, зависит от времени, локализации и степени тяжести поражения мозга. Казалось бы, ясность картине физической и психической характеристики детей с ДЦП должна дать классификация детского церебрального паралича по формам, но в настоящее время нет единой повсеместно принятой классификации. Существует ряд классификаций детского церебрального паралича. В связи с тем, что двигательные нарушения считаются основными при данном заболевании, некоторые классификации составлялись, опираясь на них. По охвату заболеванием конечностей обычно выделяются:

- тетрапарез - поражение четырех конечностей;

- гемипарез - одностороннее поражение руки и ноги;

- трипарез - поражение трех конечностей;

- монопарез - поражение одной конечности.

Такая классификация дает представление о географии двигательных нарушений, не раскрывает их характер, не учитывает психические, речевые особенности. Необходимо отметить то, что опора при классификациях на двигательные поражения оправдана, так как во многих случаях именно двигательные нарушения, являясь основными в характеристике заболевания, вызывают и усугубляют психические и речевые отклонения.

В данное время в России в основном пользуются классификацией К.А. Семеновой, которая является наиболее удобной для работы. Она включает в характеристику форм детского церебрального паралича двигательные, психические и речевые признаки. Согласно ее классификации выделяются следующие формы: спастическая диплегия, двойная гемиплегия, гиперкинетическая, атоническиастатическая и гемипаретическая формы.

К.А. Семенова также выделяет раннюю, начальную хронически-резидуальную, конечную резидуальную стадии течения заболевания.

При спастической диплегии нарушаются функции четырех конечностей (тетрапарез), но как правило, ноги поражаются в большей степени, чем руки. Руки обычно практически здоровы, иногда может наблюдаться недостаточность мелкой моторики. Обычно ноги перекрещены в области коленного сустава, стопы находятся в вытянутом положении. Ребенок обычно ходит на носочках. Относительная сохранность 
функций рук делает эту форму наиболее благоприятной в отношении реабилитации. У 60-80\% детей с этим диагнозом бывают интеллектуальные нарушения. У 70\% детей наблюдаются нарушения речи [3, с.33]. Двойная гемиплегия по характеру двигательных нарушений также является тетрапарезом. При этой форме руки и ноги поражены одинаково тяжело или руки поражены сильнее, чем ноги. Из-за тяжести поражения рук у детей обычно отсутствует хватательная, опорная способность рук. Это одна из наиболее сложных в отношении реабилитации форм. У детей с таким диагнозом наблюдается бедность или отсутствие самостоятельных движений, мимики. Им трудно изменить положение туловища самостоятельно. Они, как правило, не сидят, не стоят, не ходят. У детей наблюдаются тяжелые нарушения речи, психики, слабо развита мотивационная, волевая сфера. 45-60\% детей страдают судорогами, 30-40\% имеют патологии слуха и речи, 50-70\% страдают от микроцефалии, у 90\% снижен интеллект [1, c.90].

При гиперкинетической форме наблюдаются гиперкинезы - непроизвольные движения конечностей различного характера в сочетании с параличами и парезами или без них. Обычно при волнении, испуге, радости желание выполнить целенаправленное движение вызывает неожиданное снижение или повышение тонуса разных групп мышц, что приводит к независящим от воли, желания беспорядочным движениям. Таким детям характерно гримасничанье. Речевые нарушения наблюдаются у 90\% больных, слуховые у 25-30\% больных. У 50 \% больных встречается задержка психического развития [1, с.50]. Для реабилитации в данном случае имеет определяющее значение уровень произвольной моторики, обусловленный гиперкинезами.

Атонически-астатическая форма характеризуется парезами, низким тонусом мышц, отсутствием или недоразвитием установочных рефлексов, высокими сухожильными и периостальными рефлексами, мозжечковыми симптомами. Речевые расстройства наблюдаются у 60-70\% детей [3, с.50]. У 40-50\% детей бывают судороги. У 87-90\% детей с этим диагнозом наблюдается снижение интеллекта [1, с.98]. Эта одна из тяжелых для реабилитации форм.

При гемипаретической форме поражаются рука и нога с одной стороны туловища, рука поражается тяжелее. У детей также наблюдается замедление роста костей пораженных конечностей. Обычно пораженная рука согнута и приведена к туловищу, а нога выпрямлена. При ходьбе переставляют ноги прямо, руки не участвуют. У детей часто наблюдается нарушение знаний схемы тела. У 25-30\% наблюдается задержка психического развития, олигофрения - у 5\%. Речевые расстройства наблюдаются у 25$35 \%$ детей [1, с.47]. Эта одна из наиболее благоприятных форм для реабилитации.

На практике иногда встречаются смешанные формы, наблюдается переход из одной формы на другую. Классификации по формам не дают полной и ясной картины в отношении конкретного ребенка. Действительно, как пишет В. Г. Тактаров: “Сам термин “детский церебральный паралич” является собирательным понятием, свидетельствующим лишь о перинатальном характере поражения ЦНС плода или новорожденного, совершенно не отражающим сути происходящих процессов. С этой точки зрения, диагноз ДЦП с уточнением различных клинических форм, можно использовать лишь для традиционного описания феноменологии (подобно диагнозам “ОРВИ” или острый живот), поскольку при внешне одинаковой клинической картине и, в ряде случаев, схожем патогенезе, этиология заболевания может быть самой различной” $[3, \mathrm{c.4}]$. 
У детей с ДЦП нарушается процесс формирования речи, у многих речь так и не формируется, а также страдает и процесс восприятия и понимания обращенной речи.

Обучение пониманию значения отдельных слов является исходным в формировании речи ребенка с ДЦП.

Для достижения этой цели нужно проводить работу в следующих направлениях:

1. Дидактические упражнения, направленные на расширение сенсорного и практического опыта ребенка.

2. Коррекционно-развивающие занятия, направленные на развитие восприятия и представлений об окружающих предметах и явлениях.

ГБУ РС(Я) «РРЦ г. Нерюнгри» работает с 1992 года, за этот период сложилась система работы логопедических занятий с детьми с ДЦП. Курс реабилитации длится от 1 до 1,5 месяцев, логопедические занятия дети посещают ежедневно в течение 3 недель.

Курс начинается с проведения комплексного обследования ребенка. Составляется план системных тематических игр-занятий, направленных на развитие, обогащение лексической стороны речи.

В начале занятий с детьми проводятся упражнения, игры на активацию внимания, восприятия, затем делают различные формы массажа (массаж пальчиков и логопедический массаж), артикуляционную и дыхательную гимнастики.

Основная часть занятия, направленного развитие лексической стороны речи обязательно включает манипулирование с предметами (игрушками), знакомство с их словесными обозначениями. Так же педагогом подбираются различные задания, упражнения для формирования и расширения лексического словаря ребенка. Следует максимально использовать наглядность и опираться на совместную предметнопрактическую и игровую деятельность с ребенком. Все занятие должно стимулировать общение ребенка с помощью доступных ему реакций.

В целом, проводимая в данном направлении работа дает положительный результат, позволяет расширить лексический запас ребенка и активизировать его познавательную деятельность, моторную активность. За 2016 год из 27 обследованных и прошедших курс реабилитации детей с ДЦП выписано с улучшением 18 детей, с незначительными изменениями - 9 детей.

\section{Список литературы:}

1. Бадалян Л.О и др. Детские церебральные параличи / Бадалян Л.О., Журба Л.Т., Тимонина О.В.- Киев: Здоровья, 1988. - 326 с.

2. Семенова К.А., Махмудова Н.М. Медицинская реабилитация и социальная адаптация больных детским церебральным параличом. - Ташкент: Медицина, 1979. $488 \mathrm{c}$.

3. Тактаров В.Г. Этиопатогенез и репродуктивная функция при резидуальных формах детского церебрального паралича: Автореф. дис. ... докт. медиц. наук: 03.00.15., 14.00.01. - М., 2000. - 41 c. 